\title{
変り織の織縮に関する一考察”
}

\author{
大阪府立繊維技術研究所 知 野 光 伸 \\ 京都工芸瀻維大学 鈴 木恵
}

\section{STUDY ON THE SHRINKAGE OF THE FANCY FABRIC}

\author{
By Mitsunobu Chino**and Megumu Suzuki*** \\ ** (Textile Research Institute of Osaka Prefecture, \\ Izumiohtsu, Osaka, Japan) \\ *** (Kyoto Institute of Technology, Kyoto, Japan)
}

In designing the weaving of fancy fabrics, it is important to forecast accurately the shrinkage, whith is influenced by the yarn count, the weaving density and the warp or weft yarn tension. In this paper, these factors are investigated theoretically and experimentally on fancy fabrics of cotton and wool.

The results obtained are as follows:

1) The fabric shrinkage increases with decreasing the warp yarn tension or with decreasing both the weft yarn tension and the weaving density of weft.

2) It increases with decreasing the bending resistance and the yarn diameter.

3) It increases with increasing the deformation of the yarn cross section and with the crosspoint number in the woven structure.

4) The shrinkage of fancy fabrics $\varepsilon$, can be represented by the following expression:

$$
\varepsilon=\left\{\frac{\lambda}{\left(\frac{m}{K_{r 2}}+\frac{n}{K_{c 2}}\right)} \times 100\right\}+\varphi
$$

where, $\lambda$ is the difference of yarn intervals in on-loom and off-loom fabrics, $K_{r 2}$ and $K_{c 2}$ are the densities per $1 \mathrm{~cm}$ of non-bent and bent sections of the off-loom fabric respectively, $m$ and $n$ are the numbers of non-bent and bent sections per 1 perfection of the fabric respectively, and $\varphi$ is the shrinkage ratio of the on-loom fabric.

(Received September 27, 1977)

\section{1. 緒言}

䄉綰を正確代知ることは織物設計時に必要であること 仕言うまですなく，同時に製織中織系に加わる各種のひ ずみによる織畋後の織物の経時変化を推察することで， 既成服载断時住生ずるチェック柄の不一致などのトラブ ルを防止することもできる。

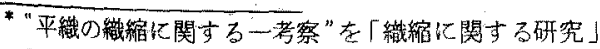
「Study on the shrinkage of the fabric」の第 1 報上 し、本報を第 2 報とする。
}

従来よりPierce ${ }^{1 /}$ 初めとして多くの研究者により織 縮は検詂されてきたが，いずれも解析を容易にするため の仮定で現害の㥀とはやや翼なった結果を生むととか多 く，特に織卸後の経時変化について言及するものはなか った。そしで，前報 ${ }^{2}$ で述べたごとき現奏の織系の状態 に類做した仮定を置き織縮在解析した。

前報 ${ }^{2)}$ で平織の織縮について迹べたが，本報では引さ 緢き平織以外の組織を持つ織物の織縮について检討を加 $\ddot{z} た 。$

なお，本解析に用いる記路仗前報”とほぼ同しである 
が，追加使用の記锌を列挙すると次のよおりである。

$P_{n} ;$ 引張張力が加わったたて系とよて系の 交差部分に生ずるそれぞれの押圧

$K_{w_{1}}, K_{f_{1}}$; 織物のたて，上こ方向 $1 \mathrm{~cm}$ 当りの機上 密度

$K_{w_{3}}, K_{f_{2}}$; 織物のたて, 上て方向 $1 \mathrm{~cm}$ 当りの織上 り密度

$l_{c} ;$ 機上に枋いて任意のよこ糸の中心加ら， それに隣接するよと系の中心までに要 するたて糸の $1 / 2$

$l_{o w} ;$ たて系亡上て糸およびよて系よたて系 との接触部分の長さの1/2

$m, n$ ；1完全組織中におけるたて系よよて系 が非届曲状態または届曲状態で交差す 万個数

$R_{w} ， R_{f} \quad$ ：機上における1完全組織中の大て系お よびよこ系の長さ

$r_{w}, r_{f}$; 張力を加える前の1完全組織中のたて 系およびよて糸の長さ

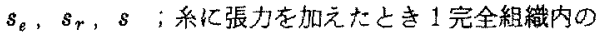
系長さ、張力を除いたときの絲の長さ および糸変形回復過程に扔りる残留伸 じ墨

$1 / K_{f \in z}, 1 / K_{w c 2} ;$ 喉曲部分のみの織上り後のたて系およ でよこ系間距離

$1 / K_{f r 2}, 1 / K_{w r 2}$; 非届曲部分のみの織上り後のたて系枋 よびょこ系間距離

\section{2. 解 析}

たて糸，よこ糸の持つ性質は前報 ${ }^{2)}$ 亡同しと考えると， 平織上外の織物の系構成はたて系书よで上て糸が必ずし 屯交互に浮き炕み(浮きとはたて糸に泩目するとたて采 がよこ系の上にある状態，㫑みとはこの逆の場合をいう） してはおらず，浮言の部分または沈みの部分が連続する 可能性加ある。

いま，系の浮き沈みを図10でとき雨端支持の連続梁 し考え，そのスパンに引張張力よいくつかある支点間の $1 つ の$ 中央に1個の集中荷重を加えたそデルを想定し た。

$T_{1}$

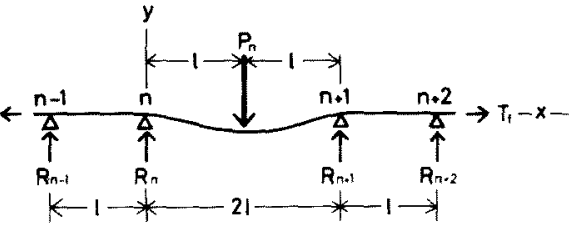

Fig. 1 Continuous beam of cloth model.
図 1 のように隣り合う二つのスパンを考える゙)。前報 より $n$ 番目のスパンの㜔み角は $M_{i}(i=n-1, n, n+1$, …)を $n$ ，または $n+1$ 点での曲げモーメント， $E I$ を曲 げかたさ， $P_{n}$ をスパン $n$ に加わる1個の集中荷重， $\alpha$ $\beta$ を係数よすると

$$
\begin{aligned}
& \theta=-\beta_{n} \frac{2 M_{n} l_{n}}{3 E I}-\alpha_{n} \frac{M_{n-1} l_{n}}{3 E I}-\gamma_{n} \frac{P_{n} l_{n}^{2}}{4 E I} \\
& \theta^{\prime}=\alpha_{n+1} \frac{M_{n+1} l_{n+1}}{3 E I}+\beta_{n+1} \frac{2 M_{n} l_{n+1}}{3 E I}+r_{n} \frac{P_{n} l_{n+1}^{2}}{4 E I}
\end{aligned}
$$

となり、とれより

$$
\theta=\left(\frac{d y}{d x}\right)_{x=0, x=2 l}=\frac{5 P_{n} l_{n}^{2}}{24 E I} \cdot \gamma_{n}
$$

ここを゙, $T_{f}$ を引張張力とすると

$$
r_{n}=\frac{1-\cosh u}{\frac{1}{2} u^{2} \cosh u}, \quad u=\left[\frac{T_{f}^{2} l_{n}^{2}}{4 E I}\right]^{1 / 2}
$$

であり，このしきの最大芜み量 $(y)_{\max }$ は単純支持梁よ り

$$
(y)_{\max }=\frac{P_{n} l_{n}^{s}}{6 E I} \cdot \frac{\tanh u-u}{\frac{1}{3} u^{s}}
$$

である。(2)式より織物の厚さんは系の断面を棈队と考 えそのときの舆軸を $a_{1}$ ，短軸を $b_{1}$ とすると平織の場合 同様

$$
\left.\begin{array}{l}
b_{1}>(y)_{\max } \text { Oとき } \\
h=2\left(3 b_{1}-\frac{P_{n} l^{3}}{6 E I} \cdot \frac{\tanh u-u}{\frac{1}{3} u^{8}}\right) \\
b_{1}=(y)_{\max } O と き \\
h=6 b_{1} \\
b_{1}<(y)_{\max } \sigma と き \\
h=2\left(b_{1}+\frac{P_{n} l_{n}^{3}}{6 E I} \cdot \frac{u-\tanh u}{\frac{1}{3} u^{8}}\right)
\end{array}\right\}
$$

となる。

平織之他の組織の織物之の相違は屈曲部之非届曲部と 加交互に規則正しく繰り返される加否加汇ある。いま， 四2に示すような系の交差を考元，そのB上Dとの交差 部を届曲部， $\mathrm{A} と \mathrm{D}$ との部分を非届曲部と呼び，1完全 組織中のそれぞれの個数を $n ， m$ とする。

図2の系B，Dの交差部分からC，Dまでの系長さを $l_{c}$ とすると図3より近似的にたて系の届曲長さ $l_{c w}, l_{c}$ 恬

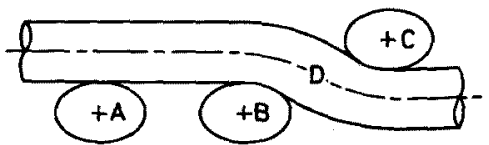

Fig. 2 Crossing model of warp yarn and weft yarn. 


$$
\begin{aligned}
l_{c w}= & \left(a_{2}+b_{1}\right) \int_{0}^{\frac{\pi}{2}}\left\{1-e^{2} \sin ^{2} \theta\right\}^{1 / 2} d \theta \\
& -\left(a_{2}+b_{1}\right) \int_{0}^{\frac{\pi}{2}-\alpha_{c}}\left\{1-e^{2} \sin ^{2} \theta\right\}^{1 / 2} d \theta \\
l_{c}= & 2\left\{\left(\frac{1}{2 K_{f 1}}-x\right)^{2}+y^{2}\right\}^{1 / 2}+2 l_{c w}
\end{aligned}
$$

となる。ただし，

$$
\begin{aligned}
& e^{2}=1-\frac{\left(b_{1}+b_{2}\right)^{2}}{\left(a_{2}+b_{1}\right)^{2}} \\
& =\frac{\left\{\frac{l}{2}\left(b_{1}+b_{2}\right)^{2}-\varepsilon\left[\left(a_{2}+b_{1}\right)^{2} \varepsilon^{2}+\left(b_{1}+b_{2}\right)^{2}\left(\frac{l^{2}}{4}-\left(a_{2}\right.\right.\right.\right.}{\left(a_{2}+b_{1}\right)^{2} \varepsilon^{2}+\frac{l^{2}}{4}\left(b_{1}+b_{2}\right)^{2}} \\
& y= \pm \frac{\left(b_{1}+b_{2}\right)}{\left(a_{2}+b_{1}\right)}\left[\left(a_{2}+b_{1}\right)^{2}-x^{2}\right]^{1 / 2} \\
& \qquad=\left(b_{1}+b_{2}\right)-\frac{(y)_{\max }}{2}
\end{aligned}
$$

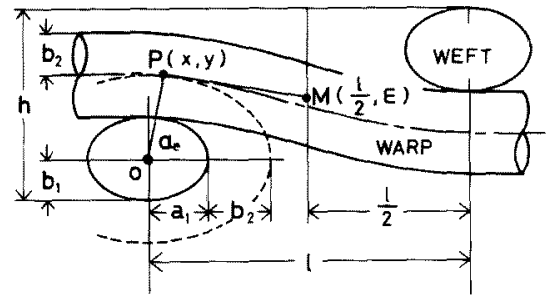$$
x=\frac{\left\{\frac{l}{2}\left(b_{1}+b_{2}\right)^{2}-\varepsilon\left[\left(a_{2}+b_{1}\right)^{2} \varepsilon^{2}+\left(b_{1}+b_{2}\right)^{2}\left(\frac{l^{2}}{4}-\left(a_{2}+b_{1}\right)^{2}\right)\right]^{1 / 2}\right\}\left(a_{2}+b_{1}\right)^{2}}{\left(a_{2}+b_{1}\right)^{2} \varepsilon^{2}+\frac{l^{2}}{4}\left(b_{1}+b_{2}\right)^{2}}
$$

Fig. 3 Cloth cross section model. where, $l=1 / K_{f 1}$

屯し，たて方问の1完全悢織中に $m$ 個の非屈曲部分上 $n$ 個の届曲部分が存在するときの1完全組織中のたて糸長 さ $R_{w}$ は (4) 式上り

$$
R_{w}=m \frac{1}{K_{f_{1}}}+n l_{c}
$$

$$
\text { となる。 }
$$

（5）式より1完全組織におりるたて糸の機上織縮率 $\varphi_{w}$ 䗆

$$
\varphi_{w}=\frac{R_{w}-\left(m_{i}+n_{i}\right) / K_{f_{1}}}{\left(m_{i}+n_{i}\right) / K_{f_{1}}} \times 100
$$

同樣によこ系の機上織縮率 $\varphi_{f}$ は

$$
\varphi_{f}=\frac{R_{f}-\left(m_{j}+n_{j}\right) / K_{w 1}}{\left(m_{j}+n_{j}\right) / K_{w_{1}}} \times 100
$$

で示すことができる。ここで， $m_{i} ， n_{i} お よ ひ ゙ m_{j} ， n_{j}$ は たて方向，上と方向の $m, n$ である。

機上において織るために各種ひずみが加えられるが， 織られた布を織機より取り出すと織系に加えられていた 外部要团による力は除加れ，時閶の経過上共に織系は元 の状態に近くなる。てれは織系目体の収縮によるもので あり，との織系を前報 ${ }^{2}$ 同様図 4 に示すどときVoigtの

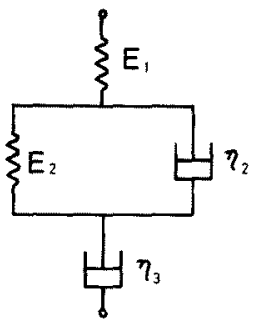

(a)

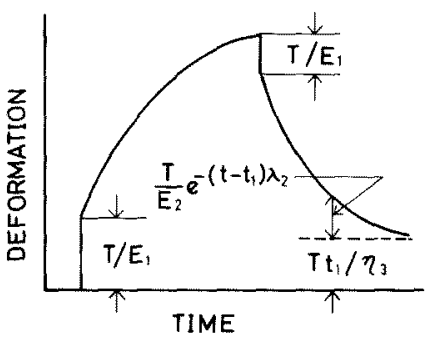

(b)

Fig. 4 Viscoelastic model of yarn.

4 要素粘弾性模形亡考える。そして，外力による織系の 伸長回復過程をそれぞれ $s_{e} ， s_{\tau}$ とすると

$$
\begin{aligned}
s_{e}= & \left\{\frac{\sigma}{E_{1}}+\frac{\sigma}{E_{2}}\left[1-\exp \left(-\frac{E_{2}}{\eta_{2}} t\right)\right]+\frac{\sigma}{\eta_{3}} t\right\} r_{w} \\
s_{r}= & \left\{\frac{\sigma}{E_{2}}\left[1-\exp \left(-\frac{E_{2}}{\eta_{2}}\right)\right] \exp \left\{-\frac{E_{2}}{\eta_{2}}\left(t_{1}-t\right)\right\}\right. \\
& \left.+\frac{1}{\eta_{s}} \sigma t\right\} r_{w}
\end{aligned}
$$

となる。ととで、のは織系に外部要因により加わる応力， $t$ は経過時間， $t_{1}$ 仗応力が加わっている間の時間である。

本解析で屯平織の場合同様䦩口運動によるたて系の伸 長，収縮は瞬間的に繰り返されるため，乙の運動による たて系の残留伸びは微小として無視する。

製織汇よる張力からの回復量 $s$ は (7) 式より

$$
\begin{aligned}
s & =\left\{\frac{\sigma}{E_{1}}+\frac{\sigma}{E_{2}}\left[1-\exp \left(-\frac{E_{2}}{\eta_{2}} t\right)\right]\right. \\
& \left.\times\left[1-\exp \left(-\frac{E_{2}}{\eta_{2}}\left(t_{1}-t\right)\right)\right]\right\} r_{w}
\end{aligned}
$$

で示される。

しかし，織物にはたて糸，上て糸相互の交差によって 届曲部分加生じ，その屈曲部分のたて系，上て系交差に よる变化距離 $\Delta k$ は屈曲角を $\theta$ よすると $\Delta k=s \cos \theta$ で示 される。これより $1 / K_{f(2,}, 1 / K_{w c 2}$ は

$\frac{1}{K_{f c 2}}=\frac{1}{K_{f 1}}\left(1-\Delta k_{f}\right), \quad \frac{1}{K_{w f 2}}=\frac{1}{K_{w 1}}\left(1-\Delta k_{w}\right)$ 
また， $1 / K_{f r 2}, 1 / K_{w r 2}$ は

$\frac{1}{K_{f r 2}}=\frac{1}{K_{f 1}}(1-s) \cdot \frac{1}{K_{w r 2}}=\frac{1}{K_{w 1}}(1-s)$

である。ここで $K_{w_{1}} ， K_{f_{1}}$ はたて，よて系の設計滵度を 示す。

よって，1完全組織における織卸後の各たて糸の移動 距離 $\lambda_{w}$ は

$$
\lambda_{w}=\left(m_{i}+n_{i}\right) \frac{1}{K_{f 1}}-\left(\frac{m_{i}}{K_{f+2}}+\frac{n_{i}}{K_{f c 2}}\right)
$$

ゆえに，たて万向の整経眭に対する織卸し布の織縮率 $\varepsilon_{w}$ およびよこ方向の織縮率 $\varepsilon_{f}$ は $(6),(8),(9)$ および(10) 式より

$$
\begin{aligned}
& \varepsilon_{w}=\left\{\frac{\lambda_{w}}{\left.\frac{m_{i}}{K_{f r 2}}+\frac{n_{i}}{K_{f c 2}} \times 100\right\}+\varphi_{w}}\right. \\
& \varepsilon_{f}=\left\{\frac{\lambda_{f}}{\left.\frac{m_{j}}{K_{w r 2}}+\frac{n_{j}}{K_{w c 2}} \times 100\right\}+\varphi_{f}}\right.
\end{aligned}
$$

となる。

(11)放よび (11-2) 式により変り織の織縮率を求め

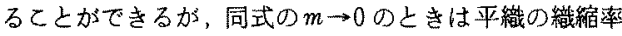
を示すととになる。また，組織の違いにより $m ， n の$ 実 数を適宣定めることで全ての織物組織の織縮率について 求るとよができる。

\section{3. 計算例および考察}

たて系およびよて系張力を考虑した式の罗当性を，綿 系 $40 \mathrm{~s}(14.7 \mathrm{tex})$ 扩よびそ毛系 $2 / 48$ 朱子織物，綾 織物について計算例と製織実験とを比較するととにより 検討した。なお，織卸後の経時変化は各々の試料につい て5時間とした。

測定方法㧍よび条件注前報”に述べた平織と同様しし， 織物は各たて系，よと系共同一系を用いた。綿織物の組 織は朱子，織り密度はたて，よてそれぞれ $2.54 \mathrm{~cm}$ 当り 80 本，130本，乙毛織物は綾織，織り密度をたて，上 こ 68 本，66本とした。使用した緎機は綿織物に東海式 綿織機，豊田織機，そ毛織物は平岩蟣機である。

製織された織物の織卸後の織縮率とたて系単系張力之 の関係罗 5 に示した。このときのたて系単系張力は綿 織物で 42.2, 48.0, $50.5 \mathrm{~g}$ の 3 種類とし， そ毛織物では $48.5,54.1 ， 60.1 \mathrm{~g}$ である。測定の結果，平織の場合上同 様，同図より明らかなように織縮率はなて系単杀張力に よって影響を受けるととが尔った。すなわち，通常製織 される筃囲 ${ }^{4)}$ では綿，そ毛織物のたて，よと系ともたて 系整系張力の増加につれて織卸後の織縮率は增加する傾

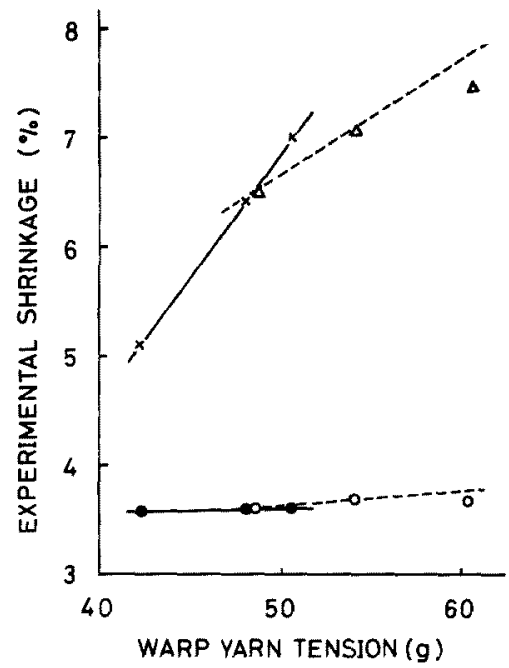

Fig. 5 The relationship between warp yarn tension and shrinkage ratio of fabric out of loom at experiment. where,

- $x$ : warp and weft line of cotton 40s (14.7 tex.) cloth

$0, \triangle:$ warp and weft line of worsted $2 / 48$ cloth

向がある。とこで, 綿織物のたて系には貶数 $75 \%$ ，PVA 糊 $25 \%$ の混合糊が糊付されている。

織縮は一般に，たて系执よびよと系が織機上で相互に 交差するため幾何学的に整経長に対し織物の織上り長さ は短かくなる。この機上での織縮率と織卸すことで織系 が収縮し，てれによって生ずる織縮みとに大別できる。 そこで，機上での織縮率について険討を加えることとし た。機上での織縮率を求めるに当たり系番手，織密度， 織組糡を知ら如ばならなととは当然でするが図 5 から 6分る様にたて采単系張力等製織条件によっても影㗽さ れる。

たて方向の機上織縮率について製織中機上で既に印加 された区闎の長さより測定された織縮率と（6)式上り計 算された犆との比較を行い，その結果を図6に示した。 なお，計算を行うに当り各系の物性は表 1 の通りとした。 同図より明らかなように計算結果と実験による結果とは 大略傾向が一致することが分る。すなわち，図6では判 明しえないがたて系単系張力が増加するにつれて計算お よび実験結果と屯機上織縮率はやや小さくなる㑯向を示 した。とれはよと系張力がある程度一定と考えられ，そ のため，たて糸単系張力が增加するにつれてたて系とよ て糸との張力差が大きくな，たて糸はよて系との交差 


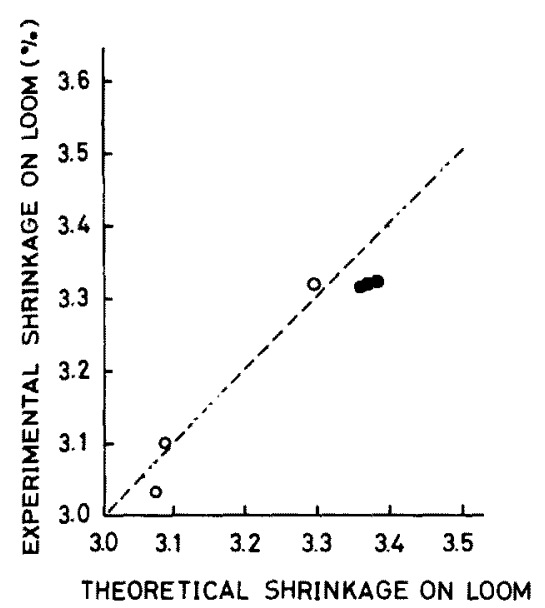

$(\%)$

Fig. 6 The relationship between shrinkage ratio of fabric of on loom at experiment and calculated one.

where,

- 0 : warp line shrinkage ratio of cotton cloth and worsted one

Table 1 Component factors of yarn.

\begin{tabular}{|cc|c|c|}
\hline \multicolumn{2}{|c|}{ sample } & cotton $40 \mathrm{~s}$ & worsted $2 / 48$ \\
\hline$D_{w}, D_{f}(\mathrm{~mm})$ & 0.154 & 0.254 \\
$E_{1} I$ & $\left(\mathrm{~g} \cdot \mathrm{mm}^{2}\right)$ & 0.289 & 0.44 \\
$E_{1}$ & $\left(\mathrm{~g} \cdot \mathrm{mm}^{-2}\right)$ & $9.62 \times 10^{5}$ & $1.06 \times 10^{5}$ \\
$E_{2}$ & $\left(\mathrm{~g} \cdot \mathrm{mm}^{-2}\right)$ & $7.31 \times 10^{5}$ & $7.35 \times 10^{4}$ \\
$\eta_{\mathrm{g}}$ & $\left(\mathrm{g} \cdot \mathrm{mm}^{-2}\right)$ & $1.86 \times 10^{7}$ & $3.77 \times 10^{6}$ \\
$\eta_{\mathrm{g}}$ & $\left(\mathrm{g} \cdot \mathrm{mm}^{-2}\right)$ & $1.26 \times 10^{6}$ & $2.49 \times 10^{6}$ \\
\hline
\end{tabular}

でよて糸より受ける荷重が相対的飞小さくなって屈曲が 少なくなる。一方，てれとは逆仙よて系はたて糸の周り を大きくうねる様になるためと考えられる。

幾上でたて糸亡上て系の交差に上り構造的に織縮んだ 各系は織卸すことにより製織中に受ける各種ひずみ，例 えば、ワープビーム，クロスビーム，テンプルによる拘 束扰より開口運動，おさ打運動による衝撃荷重がなくな り，各系はクリープ回復現象を起しながら収縮する。ク リーフ回復によりたて采，よて糸はそれぞれ収縮するが， それと同時汇たて方向，上と方向の織密度が粗加ら密へ としだいに移行する。クリープ回復乵よび織密度 $K_{f_{1}}$, $K_{w 1}$ より $K_{f 2}, K_{w 2}$ へと变化するととによる織縮は理諭 的に(11)，(11-2) 式上り求めるととができ，乙机之綿 聝物，そ毛織物について製織実験した結果とを比較検討 した。その織卸後の織縮結果を图 7 亿示した。 こてで，(11)，(11-2)式老求めるに必要な諸数値は

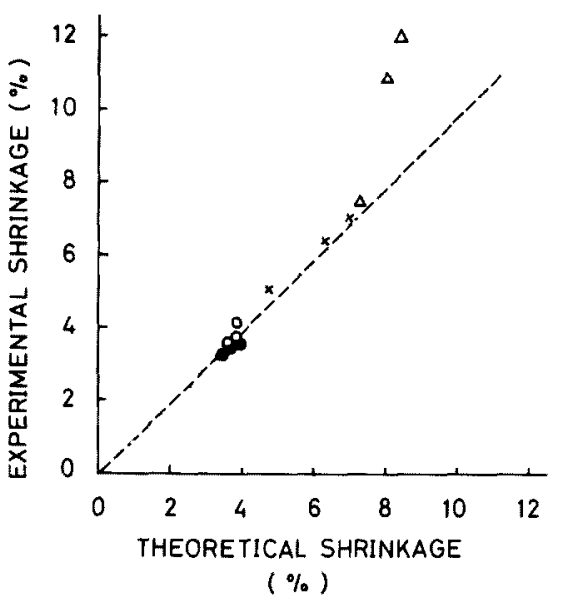

Fig. 7 Comparison of experimental data of shrinkage ratio with calculated one. where,

- $x$ : warp and weft line of cotton $40 \mathrm{~s}$ cloth

$O, \Delta:$ warp and weft line of worsted $2 / 48$ cloth

表 1 に示したが，たて系，上こ系が相互に交差すること に上る系断面形状は楕円上し，をの長軸，短軸の長さは 松田 ${ }^{5)}$ より $a_{1}=a_{2} ， b_{1}=b_{2}$ は綿系で $0.0895,0.055 \mathrm{~mm}$ ， そ毛系では 0.151，0.095 mmとした。また，製織実験で はたて系整経時たて系に前報”之同様一定長の印を入れ， この間の織縮书よびよこ方向は求さ幅に対する織物幅の 織䖝宿を測定した。図7より明らかなよう計算値と実験 值との間住良好な対応を示した。

よて方向の織縮率は計算結果より実験結果か大きい值 を示している。てれ機上織縮率の場合と同様上て系張 力をシャットルよりの解じょ張力としたととで奏際に織

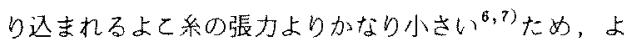
こ系のクリープ回復量が大きく，必然的に織縮率が大き くなる。一方，たて方问の織縮率むたて系張力の增加に 伴い大きくなることが分る。たて系単系張力の增加によ りたて系張力と上と系張力との間は相刘的佂差が大きく なり，上て系はたて系の周りをう好り，機上では逆にた て系の屆曲沬少なくなるが，織卸すと系の収縮加大きく なり、織密度を大とするためである。

たて系单系張力を綿系 $40 \mathrm{~s}$ (14.7 tex) で $42.2 \mathrm{~g}$ ，民毛 系2/48では $48.5 \mathrm{~g} て ゙$ 䳤織したときのクリープ回愎現象 による織縮の過程をたて力向について示したものか图 8 である。同図中の点は実験結果，実線扔よび破線はそれ ぞれ(11) 式上り求めた計算結果古示す图8 亿見られ るごとく織卸後それぞれの織物は計算結果と実験值が拉 


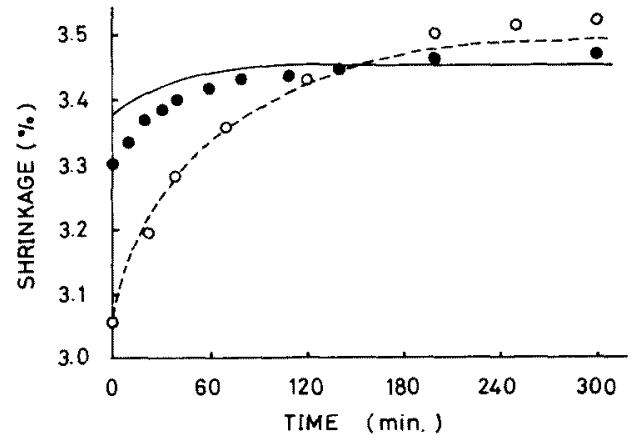

Fig. 8 The relationship between shrinkage ratio and time after taking out of loom. where,

$$
\begin{aligned}
& \text { shrinkage of cotton } 40 \mathrm{~s} \text { cloth } \\
& \text { at warp yarn tension } 42.2 \mathrm{~g} \text { and } \\
& \text { worsted } 2 / 48 \text { cloth at warp yarn } \\
& \text { tension } 48.5 \mathrm{~g} \text {. } \\
& \text { - } 0 \text { : experimental points of warp line } \\
& \text { shrinkage of cotton } 40 \mathrm{~s} \text { cloth } \\
& \text { (warp yarn tension } 42.2 \mathrm{~g} \text { ) and } \\
& \text { worsted } 2 / 48 \text { cloth (warp yarn } \\
& \text { tension } 48.5 \mathrm{~g} \text { ) }
\end{aligned}
$$

おむ极一致して収縮することか分る。また，收縮代態に つて見ると綿織物は $\eta_{2}$ が大さいため短時間で安定す るが，毛織物は綿織物に比べてク口が小さいため安定 するまで比較的長い㭙間を要することが分っだ。

以上のごとく，実験結果上計算值より変り織において も織密度の増加およびたて糸，よて糸張力の増大によっ て織縮率は大きくなり，使用系番手が緗くなるにつれて 小さくなる。そのは加同一織密度，たて禾，上と系張力 で製織するときには試料の $D_{w}$ 书よび $D_{f}$ 唯減少するとと により $a_{1}, b_{1}$ が小さくなり， $a_{1}, b_{1}$ の減少は (4) 式で分 るように織縮率を小さくする。逆に（4）式上り系断面形 状の溃れちが小さい上，また，織組織についてはたて系， よて系の交差点の多い織物はよ゙ $n$ の個数が多くなり， $m$ が少なくなるにつれて織縮㴋は大きくなるとが分った。 とのように(11)および(11-2) 式を用うるてとによ って全ての組織の織物の織縮率老求め得ることが分った。

\section{4. 結論}

前報に抋いて平織の織縮率について言及したが，本報 では織物の三原組織を含めて変り織の織縮率について検 討を加えた。三原組織在含めた変り織の織縮も基本的に は平織の場合と同様と考えてよく，ただ，平織の場合と の相違はたて系，よて系の屆曲部分と非届曲部分がある 周期で繰り返し現われるてとであり，平織の上うにたて 糸上よて糸は常に屈曲状態にはない。この点を考慮して 織系の届曲部分または非屈曲部分の系断面形状を棈円と 仮定して解析を行う之同時に実験結果よの比較を行なっ t。

その結果，变り繶においても交差角度はたて系張力の 减少またはよと糸の張力增加により大きくなる。機上織 縮率は系番手，系の演れ力，織物の組織，織密度等によ り影響を受ける。

たて系張力が增加するにつれてたて方向の機上織縮率 はあまり大きくは変化しないが，よこ方向の織縮率は增 加する。し加し，織物を織卸すととによりたて力问の織 悢率屯増加するととが分った。

同一組織，織密度，たて系外よびよこ系張力で製織す るしきは織系のEIの咸少は織縮率を小さくし，逆にク口 が小さい上きは大きくなることが分った。

付記：本研究を行うに当りご協力を睗わった七キモト 株式会社、関本南海旺氏および辰己織布株式会社、屒己 美䋶氏に感謝します。

\section{文献}

1) F. T. Peirce; J. Tex. Inst., 28, T45 (1937)

2) 知野光伸，鈴木 恵; 繊学誌, $33, T-272$ (1977)

3）た之えばS. T imosenko：「材料力学 (中巻)」, 東京 図畫株式会社，p.38(1956)

4）日本紡績拹会編，「繊維技術デー夕集」，日本絬續势 会, p. $494(1971)$

5）松田秀一；織学誌，9,351(1953)

6) 三浦義人，宇野 棯；織機誌，5，45(1952)

7) K. Greenwood, G. N. Vanghon; J. Tex. Inst., 49, T247 (1958) 